\title{
Helse og sykdom hos voksne med Downs syndrom
}

\begin{abstract}
BAKGRUNN Økende levealder hos personer med Downs syndrom krever kunnskap om tilstander som hyppig ses hos voksne med syndromet og som helsepersonell må være ekstra oppmerksomme på.
\end{abstract}

KUNNSKAPSGRUNNLAG Artikkelen er basert på litteratur funnet ved litteraturs $\emptyset \mathrm{k}$ i PubMed og forfatternes kliniske erfaringer med pasientgruppen.

RESULTATER Endret immunfunksjon, muskulær hypotoni, utviklingsforstyrrelser i hode og hals og prematur aldring bidrar til helseproblemer. Gruppen er utsatt for infeksjoner, spesielt i luftveier og i mage-tarm-kanal. Medfødte hjertefeil kan gi symptomer også i voksen alder. I tillegg utvikler mange sykdom i mitralklaffen, også de som ikke har medfødt hjertefeil. Hypotyreose utvikles hos inntil halvparten og cøliaki hos en av fem. Obstruktiv søvnapné-syndrom forekommer hos anslagsvis halvparten. Sensorinevralt hørselstap og katarakt kan ses fra før 30 års alder. Atlantoaksial instabilitet forekommer, og det skal utføres radiologisk undersøkelse av nakken før inngrep i narkose. Endret atferd med tap av ferdigheter, tilbaketrekking, psykomotorisk retardasjon og mutisme er hyppig fra 30 års alder og kan være symptomer på psykisk lidelse eller begynnende Alzheimers demens.

FORTOLKNING Det er behov for regelmessig helseundersøkelse av voksne med Downs syndrom, og vi anbefaler årlig helseundersøkelse hos fastlege. Det anbefales også screening for hørselstap og katarakt henholdsvis hvert tredje og femte år. Ved sammensatt symptomatologi, spesielt relatert til nevrologiske og psykiatriske tilstander, kan pasienten henvises til habiliteringstjenesten.

Downs syndrom er det hyppigst forekommende kromosomavviket hos mennesker, og i 2010 ble det født 69 levende barn med Downs syndrom i Norge (1,1 av 1000 levende fødte) (1). Syndromet skyldes trisomi av hele eller en del av kromosom 21 i alle eller deler av kroppens celler og er assosiert med mental retardasjon, medfødt hjertefeil, gastrointestinale forandringer, redusert nevromuskulær tonus, utviklingsavvik i hode, hals og luftveier, karakteristiske ansiktstrekk og fysiske karakteristika, endrede audiovestibulære og visuelle funksjoner samt økt forekomst av flere sykdomstilstander $(2,3)$.

Takket være medisinske fremskritt, spesielt knyttet til hjertekirurgi og kreftbehandling, er levealderen for personer med Downs syndrom økt fra gjennomsnittlig 35 år i 1982 til ca. 60 år i dag $(4,5)$. Den økte levealderen fører til at helsevesenet oftere møter voksne personer med Downs syndrom og med karakteristiske helsemessige utfordringer. I denne artikkelen gis en kortfattet oversikt over tilstander som leger bør være oppmerksomme på for denne pasientgruppen.

\section{Kunnskapsgrunnlag}

Artikkelen er basert på litteratur identifisert ved søk i databasen PubMed med emnesøkeordet «Downs syndrome» og tekstordet «adult» koblet sammen med hver av termene «aging», «Alzheimer disease», «autoimmune diseases», «cognitive impairment», «dementia», «dermatitis», «endocrine system disea- ses», «epilepsy», «eye diseases», «gastrointestinal diseases», «health», «hearing loss», «heart», «immune system diseases», «mental disorders», «musculoskeletal diseases», «neoplasms», «nervous system diseases», «obesity», «otolaryngologic diseases», «periodontal diseases», «seizures», «sleep apnea syndromes» og «thyroid gland». Søket ble avgrenset til tidsperioden 2000-12 og avsluttet $\mathrm{i}$ april 2012. Søket inneholdt ikke begrensninger på studiedesign eller artikkeltyper. Vi foretok først et søk med utgangspunkt $i$ tilstander vi ut ifra vår kliniske erfaring var kjent med at forekom hyppig hos voksne med Downs syndrom. Søket ble forbedret og utført på nytt med flere søkeord etter at vi hadde lest artikler som tilsa at flere tilstander burde inkluderes. Vi identifiserte 486 artikler, og disse ble vurdert ut fra sammendraget. Empiriske artikler og oversiktsartikler som omhandler kliniske problemstillinger hos voksne med Downs syndrom, ble lest i fulltekst $(\mathrm{n}=142)$. Ingen metaanalyser ble identifisert i søket. Artiklene som ble vurdert som mest relevante for vår problemstilling, ble inkludert. Søk i databasene Cochrane Library og Best Practice identifiserte ikke ytterligere relevante artikler. Videre bygger artikkelen på forfatternes egne kliniske erfaringer med pasientgruppen.

\section{Resultater}

Flere kliniske tilstander opptrer hyppigere hos voksne med Downs syndrom sammenliknet med resten av den voksne befolknin-

\author{
Eva Albertsen Malt \\ emal@ahus.no \\ Renate Charlotte Dahl \\ Trine Marie Haugsand \\ Ingebjørg H. Ulvestad \\ Nina Merete Emilsen \\ Børre Hansen \\ Yon Eduin Galezo Cardenas \\ Rolf Olof Skøld \\ Anne Tove Berge Thorsen \\ Eva Merete Male Davidsen \\ Avdeling voksenhabilitering \\ Akershus universitetssykehus \\ at \\ Engelsk oversettelse på www.tidsskriftet.no \\ > Se også side 263
}

\section{HOVEDBUDSKAP}

Forventet levealder for personer med Downs syndrom har økt de siste årene og er nå ca. 60 år

Syndromet er assosiert med spesifikke sykdommer og akselererte aldringsprosesser

Flere sykdomstilstander forekommer hyppigere eller tidligere hos personer med Downs syndrom

Regelmessig klinisk undersøkelse bør utføres hos fastlegen 
gen (tab 1) (6-24). Noen tilstander er knyttet til spesifikke fysiske utviklingsavvik, mens andre er antatt å skyldes akselererte aldringsprosesser $(15,25)$. For flere av tilstandene oppgis det sprikende prevalenstall. Dette skyldes først og fremst at kunnskapsgrunnlaget består av små og få studier med metodologiske ulikheter.

\section{Kognisjon}

Personer med Downs syndrom er gjennomsnittlig mildt til moderat psykisk utviklingshemmede, tilsvarende mental alder 8-9 år, men individuelle variasjoner er store (26). Nevropsykologiske tester viser at mange har en kognitiv profil med spesiell svakhet verbal hukommelse og styrke i løsning av visuospatiale oppgaver (27). Evne til planlegging og skifte av strategier er ofte svakere enn deres mentale alder skulle tilsi (28). Ved innlæring er visuell støtte viktigere enn mange repetisjoner.

\section{Fertilitet}

Kvinner er vanligvis fertile, og prevensjonsveiledning er påkrevd (15). Menn med Downs syndrom er derimot vanligvis sterile. Psykisk utviklingshemmede har generelt en økt risiko for å bli seksuelt utnyttet, og rådgivning om atferd og grensesetting kan bidra til å forebygge dette (29).

\section{Hjerte-og karsykdommer}

Symptomer på hjertesykdom er viktig å avdekke. Nær halvparten av barn med Downs syndrom har medfødt hjertefeil, og atrioventrikulær septumdefekt og ventrikkelseptumdefekt utgjør $80 \%$ av disse (10). De vil ofte kreve kardiologisk oppfølging i voksen alder, f.eks. av mitralinsuffisiens, mitralstenose, utløpsstenoser, restshunt gjennom septum, arytmier som AV-blokk, pulmonal hypertensjon og utvikling av hjertesvikt $(30,31)$. I tillegg utvikler mange sykdom i mitralklaffen, også blant dem som ikke har medfødt hjertefeil (9).

Arteriosklerose. Prevalensen av fedme har vært rapportert å være 31-47\% hos voksne med Downs syndrom, og det er vanlig å finne avvik i lipidmetabolismen, som forhøyet LDL-kolesterol og triglyserider og redusert HDL-kolesterol $(10,32)$. Til tross for dette er forekomsten av arteriosklerose lavere enn blant normalbefolkningen (10).

\section{Immunrelaterte sykdommer}

Forekomsten av immunrelaterte sykdommer er høyere ved Downs syndrom enn i den øvrige befolkningen (20).

Tabell 1 Hyppig forekommende lidelser hos voksne med Downs syndrom. Anslått prevalens oppgis i prosent og i høyre kolonne oppgis artiklene som anslagene er hentet fra. Sprikende prevalenstall skyldes små og få studier med metodologiske ulikheter

\begin{tabular}{lll} 
Medisinsk tilstand & Anslått prevalens (\%) & Referanse \\
Økt infeksjonstendens & 100 & $(6,7)$ \\
Gastrointestinale lidelser & $>70$ & $(8)$ \\
Mitralklaffprolaps & 57 & $(9,10)$ \\
Alzheimers sykdom & $50-70$ lved 60 år) & $(5,9,11)$ \\
Obstruktivt søvnapné-syndrom & $30-50$ & $(9,12)$ \\
Katarakt & $17-29$ & $(13)$ \\
Mitralklaffregurgitasjon & 17 & $(9,10)$ \\
Atlantoaksial instabilitet & 14 & $(9)$ \\
Hørselstap & $12-72$ & $(14,15)$ \\
Epilepsi & $12-46$ & $(14,16)$ \\
Psykiske lidelser & $11-30$ & $(17,18)$ \\
Keratokonus & $8-10$ & $(19)$ \\
Hypotyreose & $7-50$ & $(10)$ \\
Cøliaki & $2-18$ & $(20,21)$ \\
Diabetes type 1 & 4 & $(22,23)$ \\
Hypertyreose & $1-3$ & $(24)$ \\
Atlantoaksial subluksasjon & $1-2$ & $(9)$ \\
\hline
\end{tabular}

Infeksjoner. Redusert cellulær og humoral immunitet medfører høy forekomst av infeksjoner hos personer med Downs syndrom i alle aldre $(6,7,33)$. Spesielt hyppig ses infeksjoner i mellomøret, luftveiene og gastrointestinalkanalen (7). Pneumoni og influensa bidrar til overdødeligheten hos personer med Downs syndrom, og infeksjonsrelatert overdødelighet øker med økende alder (34).

Thyreoideasykdommer. Downs syndrom er assosiert med flere autoimmune sykdommer, og thyreoidea er hyppig affisert. Prevalensen av thyreoidealidelser ved Downs syndrom varierer i ulike studier ( $7-50 \%)$ avhengig av populasjon og diagnostiske kriterier (10). Mye tyder på at risikoen øker med alderen, og det ser ikke ut til å være kjønnsforskjeller. Hypotyreose er hyppigst forekommende, men forekomsten av hypertyreose er også lett forøket (24). Vi vil anbefale å undersøke thyreoideafunksjonen årlig hos alle med Downs syndrom (tab 2) $(14,35)$.
Cøliaki. Prevalensen av cøliaki i den generelle befolkningen er $0,3-0,5 \%$, mens forekomsten hos personer med Downs syndrom er $2,5-18,6 \%$ avhengig av pasientseleksjon og screeningmetode $(20,21,36)$.

Diabetes. Prevalensen av diabetes type 1 er funnet å være over fire ganger høyere hos personer med Downs syndrom sammenliknet med den generelle befolkningen (22).

\section{Dermatologiske sykdommer}

Atopisk dermatitt, vitiligo, alopecia areata, soppinfeksjoner i hud og negler, seboreisk eksem og tørr hud forekommer hyppigere ved Downs syndrom enn i normalbefolkningen $(15,21)$.

\section{Hørselstap}

Personer med Downs syndrom har trange øreganger, og voksansamling i ytre øregang kan føre til nedsatt hørsel. Aldersrelatert sensorinevralt hørselstap ved Downs syndrom inntrer 30-40 år tidligere enn i normal- 
Tabell 2 Anbefalinger for rutinemessig medisinsk oppfølging av voksne med Downs syndrom. Anbefalingene er utarbeidet av forfatterne, men er i stor grad basert på heftet Diagnostisering og behandling av personer med utviklingshemming og demens (35) fra Helse Sør-Øst. Heftet inneholder en norsk bearbeiding av anbefalinger fra International Association for the Scientific Study of Intellectual Disability (IASSID), WHO og Kompetansesenteret for aldring og demens

\begin{tabular}{|c|c|c|}
\hline Tidsintervall ${ }^{1}$ & Medisinsk vurdering & Kommentar \\
\hline Hver 6. måned & Tannhelse & \\
\hline \multirow[t]{9}{*}{ Årlig } & Atferdsendring & \\
\hline & Ernæring & Registrering av vekt og vektendring \\
\hline & Mage- og tarmsymptomer & \\
\hline & Hjerte- og lungesymptomer & $\begin{array}{l}\text { Auskultasjon } \\
\text { Vurdere behov for EKG, ekkokardiografi } \\
\text { og henvisning til kardiolog } \\
\text { Kardiologisk oppfølging av medfødt hjertefeil }\end{array}$ \\
\hline & Hørsel & $\begin{array}{l}\text { Klinisk vurdering årlig } \\
\text { Audiologisk undersøkelse hvert 3. år }\end{array}$ \\
\hline & Testikkelkreft & Palpasjon årlig \\
\hline & Stoffskifte & Sjekke TSH- og $T_{4}$-verdier årlig \\
\hline & Syn & $\begin{array}{l}\text { Klinisk vurdering årlig } \\
\text { Spesialistundersøkelse hvert 5. år }\end{array}$ \\
\hline & $\begin{array}{l}\text { Andre supplerende } \\
\text { undersøkelser }\end{array}$ & $\begin{array}{l}\text { Undersøke fastende glukose, hematologi, } \\
\text { SR, CRP, lever-og nyrefunksjonsprøver, } \\
\text { B }_{12} \text {, folsyre, serumjern, ferritin, lipidstatus, } \\
\text { kalsium/fosfat, D-vitamin }\end{array}$ \\
\hline \multirow[t]{3}{*}{ Annet } & Atlantoaksial instabilitet & Røntgenbilde av nakken før narkose \\
\hline & Osteoporose & Måling av beintetthet tidlig i menopausen \\
\hline & $\begin{array}{l}\text { Generelle screening- } \\
\text { undersøkelser }\end{array}$ & Følge vanlige nasjonale retningslinjer \\
\hline
\end{tabular}

1 Ved avvikende funn må kontrollene bli hyppigere og fastsettes individuelt

befolkningen og anslås å forekomme hos $12-72 \%$ avhengig av undersøkelsesmetode $(14,15)$. Regelmessig screeningundersøkelse hvert tredje år anbefales av flere $(9,35)$.

\section{Synsvansker og øyesykdommer}

Synsvansker og øyesykdommer som brytningsfeil, svekket akkomodasjon, strabisme, katarakt og keratokonus er vanlig (19). De tre førstnevnte tilstandene manifesterer seg gjerne $\mathrm{i}$ barneårene. Keratokonus oppstår hos $8-10 \%$ og oppdages ofte $\mathrm{i}$ tenårene eller tidlig i 20 -årene. Aldersrelatert katarakt kan utvikle seg i 20-30-årsalderen. Hos voksne med Downs syndrom anbefales undersøkelse hos øyelege hvert femte år, hyppigere ved avvikende funn $(13,19)$.

\section{Muskel-og skjelettsykdommer}

Voksne med Downs syndrom utvikler ofte muskel- og skjelettsykdommer, som for eksempel artritter, i relativt ung alder (4).

Atlantoaksial instabilitet. Inntil $14 \%$ av personer med Downs syndrom har tegn på atlantoaksial instabilitet ved radiologisk undersøkelse, og 1-2\% har symptomer på subluksasjon (9). Røntgenundersøkelse av nakkeryggsøylen i nøytral, flektert og eks- tendert posisjon er indisert blant annet hvis pasientene har symptomer som kan tyde på dette (9). Det skal foretas røntgenundersøkelse av nakken etter fastlagte prosedyrer hos pasienter med Downs syndrom før behandling i narkose.

Osteoporose. Downs syndrom synes å være en spesifikk sårbarhetsfaktor for utvikling av osteoporose, og både generelle frakturer og kompresjonsfrakturer i ryggsøylen forekommer hyppig (4). Medvirkende årsaksfaktorer kan være lav muskeltonus og muskelstyrke, lite fysisk aktivitet og autoimmune tilstander. Solberg og medarbeidere anbefaler beintetthetsmåling hos kvinner tidlig i menopausen (35).

\section{Obstruktiv søvnapné-syndrom}

Personer med Downs syndrom har mange risikofaktorer som disponerer for utvikling av obstruktiv søvnapné-syndrom, som utviklingsavvik i hode, hals og luftveier, overvekt og hypotyreose (12). I en mindre klinisk studie fant man at voksne pasienter med Downs syndrom hyppigere hadde alvorlig obstruktiv søvnapné med hypoksemi, hypoventilasjon og fragmentert søvn enn dem uten Downs syndrom (37).

\section{Gastrointestinale lidelser}

Utviklingsmessige avvik i det enteriske nervesystemet er knyttet til Downs syndrom, og gastrointestinale komplikasjoner kan påvises hos over $70 \%(8)$. Hos voksne er gastrointestinal refluks, dysfagi, obstipasjon, diaré, gallestein, akalasi og patologiske leverfunksjonsprøver hyppigst forekommende. Forekomsten av Hirschsprungs sykdom er forøket og ses hos 2-15\%, mot ca. $0,15 \%$ i normalbefolkningen.

Tannkjøttsykdommer. Gingivitt og periodontitt, ofte immunbetinget, er mer vanlig hos personer med Downs syndrom, og vi anbefaler halvårlige kontroller hos tannlege $(9,35)$.

\section{Kreft}

Forekomsten av kreft hos personer med Downs syndrom har en egenartet profil med sterkt forøket risiko for visse typer leukemi hos yngre barn (38). Det er også økt risiko for testikkelkreft hos menn med Downs syndrom, og flere har anbefalt årlig palpasjon av testiklene $(20,35)$. For øvrig finner man redusert risiko for solide tumorer i alle aldre (34, 38). Mekanismene bak dette er ikke fullstendig kartlagt.

\section{Sykdommer knyttet}

til sentralnervesystemet

Epilepsi. Forekomsten av epilepsi øker fra anslagsvis $2-6 \%$ i barneårene til $12-46 \%$ hos dem over 50 år (37). Anfallsdebut ser ut til å fordele seg trifasisk, med hyppigere debut i tidlig barndom, tredje dekade og etter 50-årsalderen (16). Omtrent halvparten av epilepsiene er partielle og halvparten generaliserte. Senil myoklon epilepsi er den vanligste formen i voksen alder (39). Sent debuterende anfall settes i sammenheng med nevropatologiske forandringer som ved Alzheimers sykdom. Valg av behandling retter seg etter anfallstype og epilepsisyndrom og er en spesialistoppgave.

Psykiske lidelser. Helt siden Langdon Down (1828-96) beskrev syndromet i 1866 har det rådet en oppfatning om at personer med Downs syndrom har en vennlig og imøtekommende personlighet (40). Studier bekrefter gode generelle sosiale evner med sosial forståelse tilsvarende mental alder samt en spesifikk evne til å imitere gester og mimikk $(41,42)$. Det ser ut som personer med Downs syndrom sjeldnere utvikler atferds- og følelsesmessige problemer i barne- og ungdomsårene enn personer med andre psykiske utviklingshemninger. Fra 20-30 års alder ses imidlertid økende forekomst av angst og depresjon med symptomer som tilbaketrekning, mutisme, psykomotorisk retardasjon, nedsatt stemningsleie, passivitet, redusert appetitt og søvnforstyrrelser (11). Hallusinasjoner i forbindelse med alvorlige depresjoner er ikke uvanlig. Tvangslidelser med treghet, tics og «fryserespons» forekommer relativt hyppig, særlig hos kvinner. Bipolare lidelser og schizofreni 
synes derimot å forekomme relativt sjelden hos personer med Downs syndrom. Spesielt hos kvinner er det imidlertid relativ høy forekomst av uspesifiserte psykoser kjennetegnet av lavt aggresjonsnivå, men høyt nivå av syns- og hørselshallusinasjoner (40). Samtidig har personer med Downs syndrom ofte en god innbilningsevne som kan gjøre det vanskelig å skille fantasier fra hallusinasjoner (43). Andre tegn på psykose hos pasienter med Downs syndrom er tilbaketrekning, mutisme og retarderte bevegelser, en symptomatologi liknende den depressive.

På grunn av økt sykelighet og generel forkortet levealder vil personer med Downs syndrom ofte oppleve at nære venner og medbeboere i bofellesskap dør. Stor bekymring for at foreldrene skal falle fra, er heller ikke uvanlig. Det kan oppstå kompliserte sorgprosesser fulgt av langvarig hjelpeløshet, angst og depresjon. God psykologisk forberedelse og støtte er viktig for å forebygge dette.

Alzheimers sykdom. Undersøkelser har vist at nær alle personer med Downs syndrom har utviklet nevropatologiske forandringer med amyloide plakk og nevrofibrillære floker ved 35-40 års alder (5). Forandringene er mest uttalt $i$ frontallappene og medialt i tinninglappene. Trolig kan det forklare endringer i orienteringsevne, språk, tale og sosial interaksjon som man hyppig ser hos personer med Downs syndrom over 30 år. De første tegnene til begynnende demens ved Downs syndrom er ofte endret atferd, til forskjell fra normalpopulasjonen, der redusert korttidshukommelse er det vanligste debutsymptomet (44).

Kvinner med Downs syndrom har tidligere menopause enn kvinner i normalbefolkningen, og alder ved menopause er funnet å være korrelert til alder ved debut av Alzheimers sykdom $(45,46)$. Flere medikamenter benyttes for å forsinke utviklingen av demens ved Alzheimers sykdom hos normalbefolkningen, men det foreligger få kontrollerte studier om effekt hos personer med Downs syndrom. I en nylig publisert studie der 21 personer med Downs syndrom og alvorlig kognitiv reduksjon ble randomisert til enten behandling med donepezil i 24 uker eller placebo, fant man signifikant bedring i generell og mental funksjon i intervensjonsgruppen (47). I en studie med tilsvarende design, med 52 ukers behandling med memantin, kunne man imidlertid ikke påvise effekt (48).

\section{Avsluttende kommentarer}

Fastleger og annet helsepersonell som møter voksne personer med Downs syndrom må være oppmerksomme på de spesielle helseproblemene som opptrer i denne gruppen. Vi mener det er behov for regelmessige undersøkelser med tanke på de vanligste lidelsene (tab 2) $(9,14,35)$. Personer med Downs syndrom følges opp og behandles i den vanlige primær- og spesialisthelsetjenesten. De med behov for langvarige og koordinerte tjenester har rett til å delta i ordningen med individuell plan for å sikre helhetlige, koordinerte og individuelt tilpassede tjenestetilbud. Ved omfattende og sammensatte behov kan pasienten henvises til habiliteringstjenesten. Dette gjelder spesielt der endret funksjon og atferd gjør at man mistenker sykdom i sentralnervesystemet.

\section{Eva Albertsen Malt (f. 1955)}

er overlege, dr.med. og spesialist i psykiatr med spesialkompetanse i nevropsykiatri. Forfatter har fylt ut ICMJE-skjemaet og oppgir ingen interessekonflikter.

\section{Renate Charlotte Dahl (f. 1945)}

er overlege og spesialist i nevrologi og psykiatri med spesialkompetanse i nevropsykiatri og epileptolog

Forfatter har fylt ut ICMJE-skjemaet og oppgir ingen interessekonflikter.

\section{Trine Marie Haugsand (f. 1957)}

er overlege og spesialist i nevrologi med spesialkompetanse i epileptologi og habilitering Forfatter har fylt ut ICMJE-skjemaet og oppgir ingen interessekonflikter.

\section{Ingebjørg H. Ulvestad (f. 1954)}

er overlege og spesialist i barne- og ungdomspsykiatri med spesialkompetanse i nevropsykiatri.

Forfatter har fylt ut ICMJE-skjemaet og oppgir ingen interessekonflikter.

\section{Nina Merete Emilsen (f. 1971)}

er psykolog under spesialisering i nevropsykologi.

Forfatter har fylt ut ICMJE-skjemaet og oppgir ingen interessekonflikter.

\section{Børre Hansen (f. 1966)}

er spesialist i klinisk nevropsykologi.

Forfatter har fylt ut ICMJE-skjemaet og oppgir ingen interessekonflikter.

\section{Yon Eduin Galezo Cardenas (f. 1975)}

er psykolog under spesialisering i klinisk habilitering.

Forfatter har fylt ut ICMJE-skjemaet og oppgir ingen interessekonflikter.

\section{Rolf Olof Skøld (f. 1953)}

er psykologspesialist og avdelingspsykolog. Forfatter har fylt ut ICMJE-skjemaet og oppgir ingen interessekonflikter.

\section{Anne Tove Berge Thorsen (f. 1961)}

er spesialist i klinisk habiliteringspsykologi. Forfatter har fylt ut ICMJE-skjemaet og oppgir ingen interessekonflikter.

\section{Eva Merete Male Davidsen (f. 1966)}

er spesialist i nevrologi med spesialkompetanse i voksenhabilitering og arbeider som avdelingssjef ved Avdeling voksenhabilitering Forfatter har fylt ut ICMJE-skjemaet og oppgir ingen interessekonflikter.

\section{Litteratur}

1. Medisinsk fødselsregister. Medfødte misdannelser, 2010. http://mfr-nesstar.uib.no/mfr/ (15.6.2012).

2. Van Cleve SN, Cohen WI. Part I: Clinical practice guidelines for children with Down syndrome from birth to 12 years. J Pediatr Health Care 2006; 20 : 47-54.

3. Van Cleve SN, Cannon S, Cohen WI. Part II: Clinical practice guidelines for adolescents and young adults with Down syndrome: 12 to 21 Years. J Pediatr Health Care 2006; 20: 198-205.

4. Barnhart RC, Connolly B. Aging and Down syndrome: implications for physical therapy. Phys Ther 2007: 87: 1399-406.

5. Zigman WB, Lott IT. Alzheimer's disease in Down syndrome: neurobiology and risk. Ment Retard Dev Disabil Res Rev 2007; 13: 237-46.

6. Hill DA, Gridley G, Cnattingius $S$ et al. Mortality and cancer incidence among individuals with Down syndrome. Arch Intern Med 2003; 163: 705-11.

7. Chaushu S, Yefenof E, Becker A et al. Severe impairment of secretory lg production in parotid saliva of Down Syndrome individuals. J Dent Res 2002; 81: 308-12

8. Moore SW. Down syndrome and the enteric nervous system. Pediatr Surg Int 2008; 24: 873-83.

9. Smith DS. Health care management of adults with Down syndrome. Am Fam Physician 2001; 64 : $1031-8$.

10. Vis JC, Duffels MG, Winter MM et al. Down syndrome: a cardiovascular perspective. J Intellect Disabil Res 2009: 53: 419-25.

11. Dykens EM. Psychiatric and behavioral disorders in persons with Down syndrome. Ment Retard Dev Disabil Res Rev 2007; 13: 272-8.

12. Finesilver $C$. A new age for childhood diseases. Down syndrome. RN 2002; 65: 43-8, quiz 49.

13. Puri BK, Singh I. Prevalence of cataract in adult Down's syndrome patients aged 28 to 83 years. Clin Pract Epidemol Ment Health 2007; 3: 26.

14. Määttä T, Määttä J, Tervo-Määttä T et al. Healthcare and guidelines: a population-based survey of recorded medical problems and health surveillance for people with Down syndrome. J Intellect Dev Disabil 2011; 36: 118-26.

15. Esbensen AJ. Health conditions associated with aging and end of life of adults with Down syndrome. Int Rev Res Ment Retard 2010; 39 (C) 107-26.

16. Smigielska-Kuzia J, Sobaniec W, Kulak W et al. Clinical and EEG features of epilepsy in children and adolescents in Down syndrome. $J$ Child Neurol 2009; 24: 416-20.

17. Cooper SA, van der Speck R. Epidemiology of mental ill health in adults with intellectual disabil ities. Curr Opin Psychiatry 2009; 22: 431-6.

18. Mantry D, Cooper SA, Smiley E et al. The prevalence and incidence of mental ill-health in adults with Down syndrome. J Intellect Disabil Res 2008, 52. $141-55$

19. Haugen OH, Høvding G, Riise R. Øyeforandringer ved Downs syndrom. Tidsskr Nor Lægeforen 2004 124: $186-8$

20. Goldacre MJ, Wotton CJ, Seagroatt V et al. Cancers and immune related diseases associated with Down's syndrome: a record linkage study. Arch Dis Child 2004; 89: 1014-7.

21. Roizen NJ, Patterson D. Down's syndrome. Lancet 2003: 361: 1281-9.

22. Bergholdt R, Eising S, Nerup J et al. Increased prevalence of Down's syndrome in individuals with type 1 diabetes in Denmark: A nationwide population-based study. Diabetologia 2006; 49: 1179-82.

23. Eaton WW, Pedersen MG, Atladóttir $\mathrm{HO}$ et al. The prevalence of 30 ICD-10 autoimmune diseases in Denmark. Immunol Res 2010; 47: 228-31.

24. Goday-Arno A, Cerda-Esteva M, Flores-Le-Roux JA et al. Hyperthyroidism in a population with Down syndrome (DS). Clin Endocrinol (Oxf) 2009; 71: $110-4$

25. Devenny DA, Silverman WP, Hill AL et al. Normal ageing in adults with Down's syndrome: a longitudinal study. J Intellect Disabil Res 1996; 40: 208-21.

26. Rachidi M, Lopes C. Molecular and cellular mech anisms elucidating neurocognitive basis of functional impairments associated with intellectual disability in Down syndrome. Am J Intellect Dev Disabil 2010; 115: 83-112. 
27. Lott IT, Dierssen M. Cognitive deficits and associated neurological complications in individuals with Down's syndrome. Lancet Neurol 2010; 9: 623-33.

28. Lanfranchi S, Jerman O, Dal Pont E et al. Executive function in adolescents with Down Syndrome. J Intellect Disabil Res 2010; 54: 308-19.

29. Eastgate G, Scheermeyer E, van Driel ML et al. Intellectual disability, sexuality and sexual abuse prevention - a study of family members and support workers. Aust Fam Physician 2012; 41: 135-9.

30. Martínez-Quintana E, Rodríguez-González F. Medina-Gil JM et al. Clinical outcome in Down syndrome patients with congenital heart disease. Cir Cir 2010; 78: 245-50.

31. Hayek E, Gring CN, Griffin BP. Mitral valve prolapse. Lancet 2005; 365: 507-18.

32. Nagyová A, Sustrová M, Raslová K. Serum lipid resistance to oxidation and uric acid levels in subjects with Down's syndrome. Physiol Res 2000; 49: 227-31.

33. Costa V, Sommese L, Casamassimi A et al. Impairment of circulating endothelial progenitors in Down syndrome. BMC Med Genomics 2010; 3: 40.

34. Yang Q, Rasmussen SA, Friedman JM. Mortality associated with Down's syndrome in the USA from 1983 to 1997: a population-based study. Lancet 2002: 359: 1019-25

35. Solberg KO, Davidsen EM, Lybæk KA et al. Diagnostisering og behandling av personer med utviklingshemming og demens. Ottestad: Habiliterings- tjenestene i Helse Øst, 2006.

http://ebookbrowse. com/gdoc. php?id=407221037 \&url=973c78eb5745269d32e3573217d2bdfa (15.6.2012).

36. Lundin KE, Farstad IN, Sollid LM. Cøliaki - nye kliniske erkjennelser og diagnostiske hjelpemidler. Tidsskr Nor Lægeforen 2003; 123: 3226-9.

37. Trois MS, Capone GT, Lutz JA et al. Obstructive sleep apnea in adults with Down syndrome. J Clin Sleep Med 2009; 5: 317-23.

38. Hasle H, Clemmensen IH, Mikkelsen M. Risks of leukaemia and solid tumours in individuals with Down's syndrome. Lancet 2000; 355: 165-9

39. De Simone R, Puig XS, Gélisse P et al. Senile myoclonic epilepsy: delineation of a common condition associated with Alzheimer's disease in Down syndrome. Seizure 2010; 19: 383-9.

40. Down JLH. Observations on an ethnic classification of idiots. London Hospital Reports 1866; 3: 259-62.

41. Hippolyte L, Iglesias K, Van der Linden M et al. Social reasoning skills in adults with Down syndrome: the role of language, executive functions and socio-emotional behaviour. J Intellect Disabil Res 2010; 54: 714-26.

42. Vanvuchelen M, Feys $H$, De Weerdt W. Is the good imitator-poor-talker profile syndrome-specific in Down syndrome?: evidence from standardised imitation and language measures. Res Dev Disabil 2011; 32: 148-57.

43. Capone G, Goyal P, Ares W et al. Neurobehavioral disorders in children, adolescents, and young adults with Down syndrome. Am J Med Genet C Semin Med Genet 2006; 142C: 158-72.

44. Zigman WB, Schupf N, Urv T et al. Incidence and temporal patterns of adaptive behavior change in adults with mental retardation. Am J Ment Retard 2002; 107: 161-74.

45. Schupf N, Pang D, Patel BN et al. Onset of dementia is associated with age at menopause in women with Down's syndrome. Ann Neurol 2003; 54: 433-8.

46. Lee JH, Gurney S, Pang D et al. Polymorphisms in HSD17B1: Early onset and increased risk of Alzheimer's disease in women with Down syndrome. Curr Gerontol Geriatr Res 2012; 2012: 361218.

47. Kondoh T, Kanno A, Itoh H et al. Donepezil significantly improves abilities in daily lives of female Down syndrome patients with severe cognitive impairment: a 24-week randomized, double-blind, placebo-controlled trial. Int J Psychiatry Med 2011; 41: 71-89.

48. Hanney M, Prasher V, Williams N, et al. Memantine for dementia in adults older than 40 years with Down's syndrome (MEADOWS): a randomised, double-blind, placebo-controlled trial. Lancet 2012; 379: 528-36.

Mottatt 30.3. 2012, første revisjon innsendt 26.8 2012, godkjent 20.12. 2012. Medisinsk redaktør Merete Kile Holtermann. 